https://helda.helsinki.fi

\title{
The Language of Postwar Intellectual Schmittianism
}

\section{Pankakoski, Timo}

2018

Pankakoski , T 2018 , ' The Language of Postwar Intellectual Schmittianism ' , The European Legacy, vol. 23 , no. 6 , pp. 607-627 . https://doi.org/10.1080/10848770.2018.1471917

http://hdl.handle.net/10138/308816

https://doi.org/10.1080/10848770.2018.1471917

acceptedVersion

Downloaded from Helda, University of Helsinki institutional repository.

This is an electronic reprint of the original article.

This reprint may differ from the original in pagination and typographic detail.

Please cite the original version. 


\title{
Globalizing the Political: German Radical Conservatives on the Structural Transformation of the Global Order
}

\section{Timo Pankakoski}

Centre for European Studies, University of Helsinki, Finland

[Final draft version]

Published in Global Intellectual History 4:2, 2019, 156-180

https://doi.org/10.1080/23801883.2018.1461023

\begin{abstract}
This article addresses the international political theory of German radical conservatism in its transformations from Weimar nationalism to post-WW2 adoption of a global perspective. Analyzing the work of Carl Schmitt, Ernst Jünger, and Hans Freyer - three prominent figures of the scene - I identify a paradox in their attempt to expand the nationalistic-particularistic 'political' to the global level. I focus on several shared themes that reflected and coconstituted the problem: the plurality of the political world, a 'planetary' perspective, the universalizing effects of technology and (civil) war, the philosophy of history, and the worldstate. While the parallels between the three theorists are substantial, each reacted dissimilarly to the rupture of 1945 . Schmitt historicized his theory of multipolarity and provided quasitheological groundings for political particularity. In a parallel fashion, Freyer cast world history as an empirical sum of states' political actions, causing cultural universality, yet
\end{abstract}


denied the political unity of the world. Jünger, by contrast, advocated a post- historical and post-political world-state to solve global problems. The solutions testify to the impossibility of truly globalizing the 'political' conceived nationalistically - a dilemma arguably still plaguing contemporary discussions on globalization, multipolarity, and universalism which partly recycle the notions of German radical conservatism.

\section{Introduction}

Real-world developments often push concepts to their limits and casts doubt on their applicability and consistency. The indisputable trend of globalization, for instance, has had profound effects on how we understand politics and 'the political,' and it arguably challenges these very categories. With the other central political notions, such as 'citizenship,' 'rights,' or 'legitimacy,' assuming global dimensions, can we still afford interpreting 'the political' in primarily national terms?

Rather than tackling the multi-faceted phenomenon of globalization in its entirety, I here focus on the particular issue of what happens to 'the political' in the transition to the global scale. The dilemma has been acknowledged for some time, although it is rarely addressed directly. Further, the debate on the political has been divided into sequences marked off by concrete political developments. Not long ago, in the atmosphere of relief after the Cold War, globalization was expected to bring about a condition of post-national universalism and worldwide democracy - if not the world-state, the disappearance of conflicts, and the end of history. ${ }^{1}$ This raised the question of whether global uniformity would imply the withdrawal of 
the political from the world in favor of the non-political drives of the market, underpinned by the universalizing effects of technology.

Recently, unipolarity and nascent globalism have, however, made way for neonationalism and multipolarity - with or without imperialist ramifications and the concomitant idea of spheres of influence. Questions regarding world unity and the fate of the political are now posed in a rather different key. The decisive question is now rather whether the 'escape of the political from the categorical framework of the nation-state, ${ }^{2}$, as observed in the era of post-bipolar optimism, actually meant the emergence of more varied, and consequently less controllable, forms of the political in economic, military, or cultural forms - that is, whether the liberation of the political from national bounds actually turned into a mere unleashing of powers that are of national/nationalistic origins, yet of global scale (e.g. hybrid wars, cyber attacks, or the world-wide contagion of populist neonationalism). With the 'return of the political,' the diagnosis of postpolitics and posthistoire proved to be premature; yet what keeps history running, for the theorists of this return, is precisely political differences and conflicts ${ }^{3}$, and the globalization of the political, for them, seems to lead not to 'world domestic policy"4 but to the perpetuation of ideological conflicts on the global level.

However, an element of benign universalism, necessitated by the truly planetary nature of our environmental and economic challenges, also remains. The present confusion regarding the political can arguably be traced to the peculiar combination of the globality of the problems and the remnants of nationalistic particularity in the framework in which they are addressed. The concept of 'the political' still interpreted in nationalistic terms is an essential part of the problem: no truly global concept of the political has emerged to correspond to the globality of 
the challenges, and the conclusions therefore barrenly oscillate between the equally undesirable alternatives of naïve non-political universalism and a truly politicized globe at the mercy of global civil war.

It is the task of political theorists to sketch ways out of this conundrum. Here I only venture to reformulate the problem in terms of intellectual history. I trace the key questions of the universalist/non-political and multipolar/political sequences of the debate to their mid- $20^{\text {th }}$ century German precedents and suggest uncanny parallels between how they were and are answered. The essay revisits the international and global political thought of three German intellectuals who started as radical conservatives in the interbellum era and readjusted their perspectives after 1945: the legal scholar Carl Schmitt, the sociologist and philosopher Hans Freyer, and the author and political theorist Ernst Jünger. ${ }^{5}$

I focus on Schmitt, Freyer, and Jünger, first, because they were the most prominent theorists of not only politics but also 'the political' amongst the German Right, and therefore particularly vulnerable to the problems in the attempt to scale up the political. Second, they directly tackled the larger phenomenon what we would nowadays call 'globalization' and its effects on the political form of the state - reflecting on the technologization of war, the total mobilization of resources, central planning and the totalization of states, and the consequent increasing of the spatial areas for which industrial-military plans were made. Their work paradigmatically exemplifies the conceptual problem brought about by real-world scaling-up. Third, while most Weimar radical conservatives died earlier, Schmitt, Freyer, and Jünger were active after 1945, thus having to reconsider their radically nationalistic categories, and in line with differences in their earlier thought, they reacted dissimilarly. Fourth, the three 
thinkers also interacted, adopted each other's ideas and shared a theoretical language - a cumulative discourse the main elements of which I analyze ${ }^{6}$ Crucially, language often persists longer than the challenges that provoked it; in fact, the language of radicalconservative globalization theory still affects the way current thinkers conceptualize global issues - and arguably upholds the aforementioned dilemmas. In excessively building upon what remains of the radical conservative notion of the political, present-day analysts risk making unnecessary theoretical commitments which may hinder the development of new notions of the global political.

Scholars have recently discussed Schmitt's contributions to international relations and geopolitics ${ }^{7}$, his ideas of world unity and unipolarity, and his theologically oriented philosophy of history together with its imperial underpinnings. ${ }^{8}$ Freyer and Jünger, by contrast, are not usually read as theorists of the global system, yet the comparison relativizes the role of a singular adversary of universalism often attributed to Schmitt. The relationship between Jünger's and Schmitt's post-WW2 theories of war has been noted ${ }^{9}$, and certain of my interpretative categories also utilized by others ${ }^{10}$, but no systematic comparisons of Schmitt's, Freyer's, and Jünger's global thought are available. Jünger's changing positions with regard to the political have been noted ${ }^{11}$, yet particularly my interpretative prism - the paradox of globalizing the political - has escaped the attention of previous scholars, although, I claim, this problem stands at the core of their aspirations and failures alike.

Although starting with premises reminiscent of classical IR realism, Freyer, Jünger and Schmitt analyzed global issues non-dogmatically and were attuned to the ongoing cataclysm of the nation-state and its military circumstances. The internal development of the global 
political order pointed toward a rejection of their initial nationalistic premises, yet the political seemed to simultaneously erode. Their dilemma was that of mapping the universalist dimensions of a global political community by starting with inherently particularistic premises leaning on the excluded other - a framework which had itself emerged as a result of the all-too-successful $19^{\text {th }}$-century nationalization of earlier universalistic views of global community. ${ }^{12}$ The resulting paradox took many forms. First, the military economies of scale favored larger enterprises, pushing states towards empires and leagues with spatial groundings; however, an excessively successful world empire would become non-political, as there would be no one to exclude in a globalized world. Second, the logic of material warfare necessitated the universal adoption of shared technologies and the concomitant rationalities, and war - once the paradigmatic expression of political particularity - now seemed to promote technological universalism and the dissolving of differences. Third, this conundrum was further radicalized by the WW2 experience and the nuclear threat, which compelled existential-ethical reflections with eschatological overtones: survival seemed to necessitate planetary approches, but already the universality of the problem suggested a common fate for all humanity, even though the triggering impulses were particularistic and political. Through several mechanisms, the political thus appeared to produce its own eclipse.

This pushed the radical conservatives to the largely paradoxical attempt to correspondingly 'globalize' their perspective, which was reflected in their key notions - or, rather, the paradox arose out of the interrelations of their idiosyncratic categories. I will particularly use the following intertwined elements as inlets into their global thought and its paradoxes: 1) the plurality of the political world, 2) the planetary perspective, 3) the problem of technology, 4) the question of war and civil war, 5) the aspect of the philosophy of history, and, finally, 6) 
the question of the world state. While their argumentation was remarkably similar in the first five points, with regard to the world-state they, however, differed with Schmitt and Freyer resisting and Jünger supporting it. I first engage with the radical conservatives' starting points in the Weimar Republic. The following three sections address the changes in each thinker, respectively, around the Second World War. The concluding section reassesses each of the six categories and suggests the contemporary relevance of the radical-conservative globalization discourse.

\section{Political statehood and planetary tendencies during the Weimar Republic}

Schmitt's theory of the distinction between friend and enemy as the criterion of the political has become common knowledge, and I will address it only insofar as the state, warfare, and the global order are concerned. With his notion of 'the political,' Schmitt sought to explain the intensified wars and totalized states better than the traditional vocabulary, which identified the political with the state. Although Schmitt stressed the independence of the political and anticipated the end of statehood, his normative starting point was still the classic postWestphalian nation-state: he defended its sovereignty and unlimited ius belli and resisted revolutionary politics and wars waged as ideological crusades - a tendency he attributed to the Western powers' incrimination of Germany after WWI. Already here Schmitt paradigmatically formulated the first of my analytical categories, that of plurality, postulating conceptually the existence of several states and unequivocally rejecting the world-state. 'The political world is a pluriverse, not a universe. ${ }^{13}$ The reasoning was as follows: the eventuality of wars is the criterion of the political; the humanity as a whole cannot wage wars, for it has no enemies - 'at least not on this planet,' Schmitt curiously added; therefore, a "world "state", 
that encompassed whole humanity but were still properly political was a contradiction in terms. ${ }^{14}$ Wars were still, obviously, waged in the name of humanity, but this for Schmitt was merely a propagandistic cover for political interests. Particularly the League of Nations was the Western powers' instrument to judicially legitimize their military victory and to discriminate the Germans - a universalist project, but only in the weak territorial sense of operating throughout the world, not politically. ${ }^{15}$ Despite the 'illusory fiction of world unity,' the world was still characterized by 'the pluralism of concretely existing states. ${ }^{16}$ In disclosing the ideological nature of Western universalism, these arguments were equally partisan and underpinned the German political cause. At this point, however, Schmitt theorized political structures beyond the nation-state only negatively, unveiling their false universalism.

Also Freyer theorized the plurality of states and linked the state intimately with war. Building on Hegelian philosophy, Freyer saw the state as molding the plural cultural heritage into the unity of a people and an empire (Reich). ${ }^{17}$ The state was a singular unity with a particular 'space of destiny. ${ }^{, 18}$ Both in terms of genesis and essence, war was the core of political life, because political existence required space that could only be 'conquered, consolidated and preserved' in war. ${ }^{19}$ Statehood thus implied certain 'imperialism': 'In order to exist,' the state had to conquer 'spheres of interest, areas of influence, suzerainties, vassal states and colonies,' albeit only as much as needed, and by peaceful means whenever possible. ${ }^{20}$ While in his Weimar work Schmitt mostly criticized the imperialism of others, masked as universalism, Freyer directly justified that of the Germans, turning abstract culturalphilosophical categories into political concepts that would soon eerily resonate with concrete ideological projects. 
Freyer's Hegelian cultural philosophy also implied plurality: 'Wherever meaning appears, it appears in a plurality of forms,' and a 'multitude' is never 'prestabilised into simple harmony. ${ }^{21}$ Consequently, also the political world always comprised several states. Only where political will organized peoples did states in the strong sense exist; and history was only effective in the 'concrete bodies of historical empires' that arose and sunk. ${ }^{22}$ History was in fact divided into a 'plurality' of individual states and into the 'togetherness, parallelism and polarity of political wills that responsibly advocated their respective meaningful contents in space and time' and divided the intermediary areas as their 'provinces. ${ }^{23}$ Such plurality had crucial consequences for Freyer's international thought. First, the plurality of forms precluded European unification. Rather than 'a political unity,' the 'form of the political existence' of the West was 'plurality' scattered into various national cultures. ${ }^{24}$ Second, the plurality of world history also led Freyer to explicitly reject the world-state as equally utopian as a single European Reich. ${ }^{25}$ Only alliances, rather than unions, were possible between states, and the only synthesis above them was 'the turbulent world history itself,' not any 'supra-state., 26 This was a patently Hegelian argument. Despite theorizing the transition from invididual wills to nation-states, on the one hand, and seeing nation-states as sort of individual wills, on the other, Hegel did not propose a transition to a supranational institution, but rather confined to 'suprapolitical' world history. ${ }^{27}$ Freyer's rejection of the world-state replicated the contingent limitations of Hegel's categories, yet Freyer's argument was more consistent: he elevated history into a world tribunal without any longer assuming the rational unity of history, and rather sought to maintain history's genuinely political nature. War was still the primary motor. Yet rather than the advance of the Spirit's self-consciousness, world history was a permanent struggle without an overarching principle or singular direction. The world-state 
thus appeared as hopelessly utopian and categorically precluded by the pluralism of world history and by Freyer's rejection of the remnants of Enlightenment historiography.

On this basis, we can perhaps comprehend what first appears to be a peculiar side step in Freyer's political theory. In 1930, Freyer reinterpreted Schmitt's notion of the political from the perspective of idealism, defining politics as 'the historical realization of a cultural content' or the Geist of a people. With this definition, Freyer explicitly noted, the list of the potential subjects of the political could be widened: also 'supra-state powers' like Europe, Christianity, the League of Nations, or even 'Humanity' could be carriers of the cultural idea, and in such cases individual nations should align with the larger historical force. ${ }^{28}$ To make the whole humanity a potential political subject appears to flagrantly contradict both Freyer's postulate of plurality, excluding the world state, and Schmitt's point that the humankind can never be a political subject because there would be nobody to exclude. The first contradiction, however, is only apparent: by speaking conditionally, Freyer clearly implied that none of the proposed larger political subjects currently empirically qualified as subjects in the strong sense, and, further, only contingently and temporarily could ever do so in tumultuous world history never as a permanent and final condition. However, were states led by a universal league or humanity, the situation would not be automatically non-political. The breakaway from Schmitt's conceptual rigidity seems genuine, and precisely herein appears a transient opportunity to escape the paradox of the globalized political. As will become evident, Freyer later redescribed the political again in energetic, bellicose, and particularistic terms reminiscent of Schmitt, scarcely suggesting the idea of a political humanity. However, the advantage in Freyer's conceptualization was that his permanent emphasis on empirical world 
history allowed for perceiving actual universalizing tendencies without having to postulate global political unity.

Already in the Weimar period, the most prominent unifying principle was the ethos of technology and economy, indeed 'a secular and planetary process that turns the humankind into a unified race. ${ }^{29}$ The second and third analytical categories of planetarity and technology intertwined completely. Technology was a self-contained system 'of planetary proportions' that threatened to create 'a unified world. ${ }^{, 30}$ Therefore, the political task was to divide this unity into several 'force fields' of the nation-states and turn technology into 'a political instrument of power. ${ }^{31}$ Technological progress on the planetary scale and its unifying effects had to be resisted by employing technology to national and conservative ends - a figure of thought known as 'reactionary modernism. ${ }^{, 32}$ In its linkage with nation-states, technology too became a tool of power aspirations and imperialism, and its function was to intensify the struggle over world domination rather than moderate it with unifying tendencies. While Schmitt had criticized others' particularism masked as universalism and criticized the 'satanic' nature of technology and its false universalism, Freyer argued more directly for the particularistic uses of the essentially universalistic technology. Yet the primary manifestation thereof was war - an inherently political phenomenon that paradoxically also promoted technological universality.

Also Jünger linked politics intimately with war. In his Weimar writings, Jünger sought to transpose the war experience into lessons for peacetime politics. While Freyer anticipated a 'revolution from the right' to utilize the leftist revolutionary energies and overcome feeble parliamentarianism ${ }^{33}$, Jünger equally mobilized the energies of war and revolution in favor of 
a new totalitarian order, both domestically and internationally. The manly communities of the trenches were the key remedy against democracy and internationalism, which had no 'firm grounds,' stood 'between nations' and sought to erect 'a mixture of Esperanto nations' on the basis of 'expediency' rather than 'organic ties. ${ }^{34}$ Despite its roots in nationalistic sentiments, Jünger's solution to the problems of political modernity, however, had unmistakable global characteristics that matched the global nature of the problem. The modern world was unified under the banner of progress, and 'the great principles of reason,' Jünger sarcastically noted, had gained 'planetary dominion' at the cost of ideological wars and civil wars. ${ }^{35}$ With the diffusion of European values, 'the surface of Europe' had gone through 'a planetary expansion,' yet the powerless continent itself had become a mere 'veneer., ${ }^{36}$ This weak liberal globality was to be replaced by a global constellation of nationalistic powers - another manifestation of the particularism/universalism paradox, which becomes comprehensible in the light of Jünger's idiosyncratic understanding of nationalism. Nations were constantly threatened from without by other armed nations, yet Jünger's nationalism allowed for chivalry respect for the enemy and rival cultures, by no means representing their extermination as desirable or feasible. Rather the humankind would be best served if each nation brought its best impulses into global competition instead of turning everything into a single 'hopeless mush. ${ }^{37}$ To draw distinctions and respect national boundaries was the key, not to negate other political entities. Jünger's nationalism thus pertained to the citizens' existential political commitment to the state's cause, and other such communities of fate also existed per definitionem. The plurality of the political world was, again, implied.

Further, the political impetus of the war experience to nation-building was equally available to all countries, and Jünger's nationalism was thus 'energetic' rather than 'substantial.' 
Therefore Jünger could build global dimensions into his authoritarianism without contradicting his nationalism. In 1932, Jünger argued that bourgeois societies would be overcome by a novel political order organized around the mythical figure of the worker, emerging from the trenches. ${ }^{38}$ Carrying both military and proletarian traits, the new order would implement military obedience and comprehensive socialist planning. While in his political essays Jünger theorized the new type of human being emerging from the trenches, he now anticipated the world to be reinterpreted in terms of work and a whole new 'order of the world' to emerge through 'wars and civil wars. ${ }^{39}$ This, Jünger reasoned, not only enabled but also required 'global dominance': The worker's sphere of operations was indeed the 'globe' comprehended as a 'unity,' and the worker thus had a 'planetary function. ${ }^{40}$

Anticipating an 'imperial turn' around the globe and the rise of the worker to meet its 'claim for planetary validity, ${ }^{41}$ Jünger, however, said little unequivocal about how the novel order would emerge. Alongside war and global revolutionary action, the key vehicle for workers' global influence was, again, technology, which imposed its language on every domain and thereby weakened the traditional bastions of bourgeois power, such as Christianity. ${ }^{42}$ Although 'nihilistic' per se, technology prepared necessary structural changes globally and thus promoted a 'total revolution. ${ }^{43}$ Technology's ability to spread rapidly throughout the world $^{44}$ - its global nature - was crucial. While Freyer had similarly observed technology's 'planetary' power and the need to employ it to conservative ends, Jünger gave the argument a radical twist by underscoring both the nihilism of technology and the impetus of world revolutions as key elements of the anticipated global turn. Planetarity and technology were closely intertwined for both, but Freyer firmly defended political plurality against false 
universalism, whereas Jünger sought to exploit technology for the unification of the world under conservative signs.

With these Weimar arguments, the baseline for my further analysis is set. All three tied the aspect of the political conceptually with plurality and war as well as acknowledged the universalizing effects of technology and the emerging planetary perspective. Schmitt and Freyer felt the push beyond the nation state, yet still operated within that framework, nurturing the particularistic 'political' and explicitly rejecting the world state. Jünger's thought, by contrast, carried distinctively global traits already here ${ }^{45}$, and this would later determine the parting of their ways. None of them, however, at this stage sought to ground their global theory significantly in a theology or philosophy of history, as for instance Wilhelm Stapel did in his 1932 call for a planetary German empire, which would unite the world in anticipation of the Christ and, in the absence of resistance, terminate world history. ${ }^{46}$ Eschatology only entered their global thought during WW2, and the rupture of 1945 intensified the paradox inherent in the attempt to globalize the political conceived in particularistic categories. I will next address their reactions in the altered situation individually.

\section{Schmitt: Spatial plurality against world unity}

During the Third Reich, Schmitt legitimized Nazi policies legally and theoretically. It is, however, only after his breach with the regime around 1936 that Schmitt began creatively theorizing the international order. He called for novel structures to reanchor 'the political' set loose from the nation state framework, and this provoked some of his most notorious notions. 
From 1939 onwards, Schmitt perceived a fundamental shift with regard to the idea of space (Raum). The spatial grounds for international law were being revolutionized by a transition to an order based on the category of 'greater space' (Großraum) rather than the state. This development had a double root. First, it was driven by economic interests: a Großraum was 'an area of human planning, organisation and activity,' and the very concept derived from technical, industrial, and organisatory considerations. ${ }^{47}$ Second, the Großraum perspective arose as a result of states' political action. The deeds of the Führer created a strong German Reich capable of 'radiating' its ideology all over Europe, making Großraum and Reich the key concepts of the international order. ${ }^{48}$

This primarily economic and political shift also had legal and military ramifications. International law applied only between greater spaces, not within them, as dictated by Schmitt's principle of non-intervention, modelled after the Monroe Doctrine. Greater spaces would be like traditional states in many respects: there would be trade and diplomacy between them, and they still enjoyed unlimited jus belli and full sovereignty within their territory. The world order still was a balance of power, which required a plurality of greater spaces. In shifting to continental proportions Schmitt thus retained the key structural features of his nationalistic Weimar theory. However, Schmitt warned against mechanically extending the legal categories of states and peoples onto greater spaces, since they were historically bound up with 'Anglo-Saxon world-imperialism' and belonged to the 'planetary law of nations' that had emerged in early modernity with the extension of European notions into 'the planetary space. ${ }^{49}$ This undesirable planetary universalism was to be replaced by a benign German 'planetary' Großraum perspective that would transgress 'universalistic-imperialistic global 
law' with a novel view corresponding to the German notions of the state and the people. ${ }^{50}$ Like Jünger, Schmitt was destined to substitute one form of planetarity for another.

While liberal universalism sought to regulate political wars between states by judicial instruments, Schmitt was after a political solution. Rather than abstract normative categories, the containment of war would be based on spatial segregation into power blocks, each with their own sphere of operations and own notions of war. ${ }^{51}$ Großraum thought was thus the opposite of universalism, and although Schmitt failed to specify what made the German version less imperialistic, the upshot was that the division of the world into interest spheres secured global peace. Wars would be fought, free of normative-universalist constraints, between greater spaces, but their mutual recognition guaranteed duel-like limited warfare, and their space-boundedness secured a strong peace. Schmitt saw the on-going war as the first 'planetary war of space order' that, correspondingly, could only be ended by a 'peace based on an order of space. ${ }^{, 52}$ Due to their spatial component, greater spaces were capable of demarcating friends and enemies better than traditional states whose enemies lied within. Based on Western universalistic normativism, wars would become ideological and intense 'international world civil war' ${ }^{, 53}$ - and permanent. The Großraum structure, by contrast, provided the necessary spatial groundings for world peace, indeed the Earth's new 'nomos,' i.e. order.

In order to criticize current universalism, Schmitt's Nomos of the Earth (1950) engaged historically with earlier attempts to reflect the globe as a political entity. Written during the war, the book bitterly chronicled the decay of Eurocentric world order, recycling the above space-related arguments with added historical insights. Schmitt now increasingly introduced 
'global' and 'planetary' to his vocabulary, being generally concerned with the Nomos of the whole globe. ${ }^{54}$ However, Schmitt still promoted the balance of Großräume as a solution, now rather historically scrutinizing the reasons for its dismissal despite the empirical rise of Großräume as economic-political factors. The unsurprising culprits were the Monroe Doctrine and the League of Nations' 'spaceless' principles - the result the dissolution of the European balance into 'global civil war. ${ }^{55}$ For Schmitt, the Cold War predicament was thus a direct consequence of the judicial regulation of political affairs and the concomitant intensification of hostilities. Paradoxically, the answer to the genuinely global problem of pacifying the Earth could only arise out of unconstrained political particularism. Yet complete global domination was ruled out by Schmitt's basic postulates; his solution was a division of space between at least two, but preferably more power centers by a contingent equilibrium arising out of political war.

From 1950 onwards, Schmitt's arguments against universalism and world unity relied increasingly on philosophy and theology of history, the fifth of our interpretative themes. Without considering their admittedly speculative basis we cannot fully comprehend Schmitt's institutional propositions, and the same goes for Freyer and Jünger. Having previously observed an increase in the size of the spatial units of planning, Schmitt criticized such planning as based on unfounded historical-philosophical categories. Interestingly, the key ideas derived from Freyer's criticism of the philosophy of history and his analysis of dominion and planning ${ }^{56}$, which in turn utilized Schmitt's political categories. 'The planning and leading elites,' whether Marxian or liberal, invoked the philosophy of history to justify plans and located themselves on the side of the coming things. ${ }^{57}$ Schmitt credited Karl Löwith for showing how all such constructions were forms of secularized eschatology, and proceeded 
to analyze whether eschatology and history were compatible in the first place. If the apocalypse was imminent, there was little room for properly historical action; however, the same stagnation followed from cyclical views of history, such as Nietzsche's eternal return of the same, Schmitt reasoned. This was the theoretical dilemma that not only occupied Schmitt personally in the post-war era when his country and career were both in ruins, but also determined his positions with regard to the global order.

Schmitt himself aimed at a view where history still continued (rather than being terminated with the eschaton), where the direction of history was open (rather than predestined by inevitable progress) and where concrete historical actions were seen as unique (rather than history endlessly repeating itself). To this end he introduced the katechon, the force that restrained the end of the world, which he had developed since 1942, but here explicitly attributed to Freyer's Weltgeschichte Europas. ${ }^{58}$ The katechon not only upheld history in the abstract sense, but, as history was the site of all political action, also the condition where political distinctions could still be made. Schmitt anticipated that before the end of the world, all differences would dispel and the unity of the world emerge. ${ }^{59}$ His resistance of world unification and unipolarity thus had theological underpinnings: at least one counter-power was needed to resist the Antichrist. Further, as technology was the key catalyst of planetary uniformity and apparent neutralization of political conflicts, Schmitt's early depiction of the 'satanic' nature of technology fitted the scheme perfectly.

In institutional terms, Schmitt asked whether the world would consist of one, two, or several power constellations, himself advocating a 'pluralistic' view. First, he denied the existence of a single political center despite various biological, theological and technical-commercial 
unification tendencies. ${ }^{60}$ The current East/West opposition would not become a unity, as postulated by both liberal and socialist philosophies of history, but a 'plurality' of Großräume with a balance of power similar to that in the traditional ius publicum europaeum. ${ }^{61}$ The reason for this belief, Schmitt explicitly noted, was that he did not share the philosophy of history that postulated a single telos whether in Hegelian terms or as the inevitable progress proposed by liberalism. ${ }^{62}$ Particularly the restraining katechon figure thus precluded world unification.

Second, duality was equally untenable. While earlier identifying world unity with unilinear philosophies of history, in 1955 Schmitt resisted the Nietzschen philosophy of eternal return which he perceived as manifesting in how Jünger presented the East/west division as an eternal metaphysical dualism. The interplay of impulses and counter-impulses would reiterate the polar opposition in endlessly new variants, while Schmitt was after truly historical uniqueness. ${ }^{63}$ This consideration also determined his position with regard to the world-state that Jünger anticipated, which would uphold the eternal return, whereas for Schmitt everything was true only once. ${ }^{64}$ Schmitt's rejection of the world-state thus built on a philosophical rejection of not only the unilinear idea of world unity, but also of cyclical conceptions of time. To erect a world-state on a dualist basis would be even worse than founding it upon universalism, for this would combine unity with duality, and the latter in Schmitt's personal semantics implied civil war. ${ }^{65}$ Should the two superpowers unite for pragmatic reasons, it would only be an apparent peace.

In 1962, Schmitt then historicized these questions, considering the Cold War in three phrases. Cold War's roots, Schmitt claimed, went back to 1943 and the common belief by both the 
USA and the Soviet Union that universal peace and world unity would ensue with a victory over Nazi Germany. In the second phase, starting in 1947, the originally illusionary monism was replaced by a bipolar structure and enmity between the two superpowers. Only 'progressive utopias and technological fantasies' remained of world unity, and the incapability of the United Nations reflected the central division. ${ }^{66}$ Currently, with the dissolution of earlier colonial structures and the industrialization of underdeveloped countries, the world was going through the third phrase, a transition to a 'pluralistic and multipolar structure' of several Großraum formations. ${ }^{67}$ Schmitt now empirically observed the development from duality toward plurality (rather than unity), which he earlier assumed purely philosophically.

Schmitt's theology of history precluded unipolarity, identified with being non-political, while his theory of the political ruled out bipolarity, identified with civil war. Against these two evils, the postulate of pluralism served simultaneously both to uphold the political condition and to guard against global civil war. The over-determined assumption, despite its nationalistic-particularistic origins, thus formed the backbone of Schmitt's global theory. Yet, another 'recovering Hegelian' shared the presupposition and resisted world unity with parallel categories - and arguably more successfully.

\section{Freyer: Universal history driven by political particularity}

Also Freyer mapped the philosophical-theological basis of the emerging world order. As noted, Schmitt adopted from Freyer the katechon figure and the link between planning and philosophy of history. Whereas Schmitt advocated a particular philosophy of history aiming 
at upholding the historical condition, Freyer pursued this goal by, at least nominally, criticizing all forms of the philosophy of history and particularly that of his one-time inspirer Hegel. Freyer's strategy, particularly in Weltgeschichte Europas (1948), was to mold world history as an empirical sum of numerous political actors' voluntaristic impulses and to reflect it at large. The apparent world unity in historical terms was always underpinned by political plurality, he argued. To guard the pluralism, however, Freyer equally introduced 'restraining forces' that hindered the increasing uniformity caused by industrialization - and thus arguably grounded his observations on a particular philosophy of history, not at all unlike Schmitt's. Deriving from the 1948 volume, this aspect was crucial in Freyer's Theorie des gegenwärtigen Zeitalters (1955), an ostensibly moderate cultural critique of the industrial societies, building, however, largely on Freyer's prewar radicalism, and calling for conservative counter-forces. Schmitt was impressed by how Freyer captured the dilemma of the present historical situation. However, while Schmitt's strategy was to directly disclose the ideological imperialism behind any apparent universality, the backbone of Freyer's analysis was a historical relativization of universality into the effects of particular political deeds by powerful nations.

Freyer underscored European impulses in global affairs, yet rejected the idea of a uniform world history as a secularized theological idea deriving from Enlightenment philosophy rather than a properly historical postulate. ${ }^{68}$ In $19^{\text {th }}$-century realist historiography, the belief in world unity dispelled and history was parcelled into peoples, states and empires. ${ }^{69}$ Such historicism largely harmonized with Freyer's political theory of a plurality of states, each making their autonomous political decisions and affecting the course of history. Rather than an everpresent universal category, politics was to be understood as an ingredient of particular 
historical situations in which states or imperia made consicous decisions to risk their existence in historical struggles. ${ }^{70}$ This framing of the political derived from Freyer's prewar work. In harmony with Schmitt's criticism against neutralizations, Freyer identified a $19^{\text {th }}-$ century attempt to privatize morality, identify the political with the economical and thus perform a 'conjuring away of the political. ${ }^{, 71}$ The political, however, could not be secularized, neutralized or naturalized, since it was a 'quintessence' of earthly and historical humanity. ${ }^{72}$ Freyer linked the political with manifestions of national particularity in history as well as described it in energetic terms: rather than an abstract framework, the political was the precondition for 'this particular religion, this art, this science and philosophy,' and with Machiavelli he underlined that there were no abstract rules for right conduct, but that the unevenly distributed political substance of virtù was what made the difference. ${ }^{73}$ Politics and historical particularity were thus co-extensive. Rather than a universal or ever-present quality, the political was an energetic principle that allowed political nations to make their mark in world history, thereby creating particularly political epochs.

This stress on particularity, however, did not preclude historical forces' empirical universal effects. Numerous historical moments took world history forward, such as the invention of the military chariot, the medieval migrations, the voyages of discovery or the Holy Roman Empire as a universal force that carried the heritage of Rome. ${ }^{74}$ Europe and other historical powers had pushed world history toward illusory unity, although the humankind was not a unified subject of history and world history was a unity only apparently. ${ }^{75}$ Globality and planetarity were thus not to be confused with political or historical unity, which was still precluded by Freyer's revised Hegelianism. There were two principal causes for global effects. First, the universalizing effects stood on political grounds: particularly imperialism 
and colonialism played a key role. Like Schmitt, Freyer posited that precisely the expansion of intra-European conflicts onto surrogate objects enabled the relative pacification of Europe ${ }^{76}$ But as Europe itself was not a unity, the global expansion of European impulses in the colonial era brought about a 'plurality' of power positions, all with their imperialistic aims. ${ }^{77}$ This caused 'an expansion of Europe and its conflicts in distant spaces. ${ }^{78}$ With colonialism, the germ that emerged in Europe 'infected the whole planet' - 'a genuine restructuring of the political Earth, a recharging of distant spaces with world-historical energies,' indeed 'a planetary process,' took place. ${ }^{79}$

Second, another key factor was, again, technology. In modernity, political decisions affected world affairs through technology, and only highly industrialized states had a say in world politics. The world had industrialized as a result of European initiatives, and only in the era of technology could world history shed its European core and become truly global. While earlier the universal impulses had mostly come from Europe, after rougly 1860, Freyer claimed, world unity was promoted by other areas, such as the US and Russia, and European world history thereby turned into genuine 'world history of the whole Earth. ${ }^{80}$ Industry became a 'politicum,' and a new labile balance of industrial powers emerged and 'closed around the planet. ${ }^{81}$ In his influential criticism of the industrial society, Freyer called this new structure the artificial layer of 'secondary systems' that, lying 'all around the planet,' insulated modern societies from the organic national basis. ${ }^{82}$ Technological and moral progress standardized the life of all nations, and a particular type of civilized human being spread 'all over the Earth. ${ }^{, 83}$

Technology implied planetarity, but the motive was political. Based on his prewar affirmative analysis of 'planning,' Freyer now criticized ideological planning - that is, socialist and 
liberal attempts to make world a perfect place by following a blueprint allegedly necessitated by history, an idea directly continuing early-modern utopianism. Yet with the new structure of the political Earth, the political units for which planning was done had grown out of proportions. Liberal politics was still utopian, but with the advance from small states to large nations, federations and continental formations, the island of traditional utopias had turned into 'greater space [Großraum], continent, or, in the extreme case, planet. ${ }^{84}$ Rather than endorsing this development, Freyer noted it empirically and critically with respect to his concerns about ideological planning. Nevertheless, the plurality of greater spaces also meant that cultural uniformity was not complete and that movements in world history could still radiate from the greater spaces controlled by particular nations. In especially 'global-historical situations,' restricted particularity and 'the pluralism of the historical world' temporarily captured 'the universal order' and supported it, thereby becoming durable and consequential historical forces. ${ }^{85}$ In other words, particular political forces upheld universal history in turns, and universalism thus fed on particularity. Defined as particularity with universal historical effects, the political could be expanded spatially, and in fact Freyer followed Schmitt in noting how European religious tensions went global in the battle of Catholicism and Protestantism in and for the colonies, which turned European politics into 'world history' and expressed 'pure political existence. ${ }^{, 86}$

The Cold War oppositions manifested this globalization of European impulses, yet precisely the particularity of political prowess set limits to the universalizing process. The increased size of political units, the decrease of their number, or their occasional universalistic missions did not bring a 'final unity of the whole Earth' any closer. ${ }^{87}$ The humanity had never been a single entity with unified goals and plans, but rather always divided and 'loaded with 
enormous tensions. ${ }^{, 88}$ Any idea of unity was mere secularized eschatology: 'The promised victory of the Church before the end of the world has turned into the one world moved together by technology, transportation and politics and now organizable for any given future. $^{89}$

For Freyer, the one world was an illusion, because national differentials still loomed large. If one wanted to reflect upon the Earth as a single globe, it resembled a 'space ship' with no unified crew or leaders and with all conflicts taken on board. ${ }^{90}$ In fact, a paradoxical downside of the widened planetary perspective was that it underlined internal tensions. This problem followed from Freyer's depiction of world history as an empirical sum of particularistic forces' universal effects. The engagement with world history, rather than mere national histories, opened the door for the idea of international conflicts as internal strifes of a single humanity - a position Freyer's premises denied, but his historical speculations suggested.

Freyer's post-Hegelian approach was significantly better equipped to deal with the paradox of globalizing the political than Schmitt's; yet also his categories implied that political particularity produced universalism through war and technology, and to counter this unifying tendency, both thinkers resorted to the theology of history. With unification thus theoretically excluded, the adopted planetary perspective could, conceptually, only mean a condition of latent or actual civil wars between the planet's inhabitants. Before returning to this paradox in my concluding section, I will, however, explicate how Jünger dealt with the problem.

\section{Jünger: Post-history and the post-political world-state}


As noted, Jünger's Der Arbeiter endorsed a planetary perspective. Yet only his postwar work explicitly addressed world unification - in a different key. The shift from nation-states to globality can be traced to Jünger's wartime diaries: in 1943, disillusined with the nationalistic war effort, Jünger identified himself as simultaneously 'a Welf, a Prussian, a citizen of Greater Germany, a European and a citizen of the world. ${ }^{91}$ In light of the earlier planetary aspects, this was, however, a shift of emphasis rather than a rupture. When Jünger published his 'Der Friede' ('Peace,' 1945), the world situation had altered profoundly, as had his thoughts. The essay was ostensibly a pacifistic call for a lasting peace, seasoned with theological elements. Jünger turned from existential affirmation of battle to stressing the planetary consequences of war and the desired qualities of the anticipated peace. While earlier cherishing planetary revolutionary action under conservative signs, he now pejoratively diagnosed a planetary division: 'As sons of the Earth, we are in civil war, in fraternal strife,' indeed a 'global civil war' (Weltbürgerkrieg). ${ }^{92}$ The war - the first collective effort of the humankind - had turned the Earth as a 'globe' (Kugel) into a battlefield; correspondingly, the peace to truly end the smouldering conflict would have to encompass the whole planet and its population, Jünger proposed, echoing Schmitt's spatial notion of peace. ${ }^{93}$ Strong pacts were needed to end the fraternal strife, but a peace in a stronger sense required synodal dimensions and the churches to reunite against nihilism. ${ }^{94}$ Having earlier valued the nihilism inherent in technology for its ability to wreck ecclesiastic structures, Jünger now adopted a theological perspective to counter the nihilism of a completely technologized world.

The political remedy, however, was the consolidation of nation-states into larger wholes. Human history now urged 'a planetary order' and 'the division of the earth into great living spaces [große Lebensräume]. ${ }^{95}$ New federations and 'greater Reichs' would emerge, and a 
balance of continents and empires, rather than nations, would maintain world order. ${ }^{96}$ This perspective made Jünger an advocate of European unification: a new 'order of space' (Raumordnung) would arise and provide Europe with 'geopolitical unity. ${ }^{97}$ The affinity with Schmitt's categories is apparent; yet whereas Schmitt first advocated a German-led greater space and after WW2 reflected upon the various nomoi of the Earth only historically, Jünger rather supported a politically unified Europe on the basis of voluntary contracts, rather than force, and by respecting both unity and diversity. This was a perceivable breakaway from radical conservative premises. Moreover, the European greater space was only an intermediary step towards a world-state (Weltstaat). The objectives of the humankind were no longer on the level of nation-states or greater spaces, but pertained to 'the planet altogether., 98

This shift of scale from nation-states through Großraum formations to planetarity recurred in particularly in Jünger's World-State (1960). The foundations of the state had become elastic: through the expansion of the areas for which plans were made, Jünger noted with Freyer, states not only encompassed larger populations but had also changed qualitatively. ${ }^{99}$ Currently the 'globe' (Globus) was divided by two massive states with absolute sovereignty over a territory. ${ }^{100}$ Nevertheless, increasing uniformity and a 'global style' was perceivable in the production of similar forms, such as the appeals to the shared categories of 'peace,' 'freedom' and 'democracy' or the use of the same technology. ${ }^{101}$ Jünger's anticipation of a world-state, however, was not so much based on observed cultural unification, but, first, on the expediency of a global power structure given the planetary tasks and, second, its quasicausal inevitability. The world-state was not only desirable but also already in process just like a caterpillar would become a butterfly with respect to its inherent final causes. ${ }^{102}$ In fact a 'planetary order' and a transition to a world-state or 'world imperium' (Weltreich) was 
already 'consummated' and only had to be acknowledged. ${ }^{103}$ A global state was arising, because it must.

While Schmitt and Freyer explicitly denied that the Cold War duality would be a step from plurality toward world unity, Jünger asserted precisely this. The situation of two 'worldstates' was untenable, as the very idea of a world-state excluded 'plurality., ${ }^{104}$ A single worldstate had to emerge for conceptual reasons. This, however, did not stop Jünger from maintaining the postulate of the state form being 'determined by pluralism' - he now only observed that historically this had not always been the case and anticipated a single state to reintroduce a condition where, in the absence of rivalry, no armies were needed. ${ }^{105}$ Military and economic competition would cease, armies would become police forces, and 'Earth plans' would replace state plans. ${ }^{106}$ A single superstate in a stateless world was the precondition of genuine planetary peace. This was so not despite Jünger's agonistic belief in the inevitability of warfare but precisely therefore: while Schmitt believed in the political solution of containing war by balances of power and spatial segragation, Jünger's either/or only allowed the eradication of states, the subjects of war. His moderate pacifism was thus intellectually more radical than Schmitt's balancing act. Further, wars waged as police operations horrified Schmitt, but here, too, Jünger transcended his innate nationalism.

In addition to this political framing and human history, the world-state also arose from the considerations of 'the history of the Earth. ${ }^{107}$ The planetary perspective beyond mere internationalism allowed for the demarcation of human time from the time of nature and the relativization of human civilization vis-à-vis long-term natural processes. The Earth was presently in distress in terms of climate change, as Jünger observed significantly early on. 
Jünger noted the possibility of global warming by a few degrees, the consequent glacier melt, the loss of land, 'ethnic invasions,' and - with almonds growing in Norway - 'a new global style. ${ }^{108}$ Behind anticipated cultural unification thus laid a genuinely planetary problem that the emerging world-state needed to address, thus paradoxically postponing rather than endorsing cultural universality.

However, the intellectual price Jünger paid for this aspect of utility was enormous. First, in contrast to Schmitt's aspirations, such a world order would be thoroughly non-political in the sense implied by the radical conservative view of the political world consisting of several sovereign units with their respective areas, interests and cultures. As Schmitt underlined the eventuality of war as the criterion of the political, Jünger's world-state would, for Schmitt, be a non-political or post-political condition - and unattainable. In fact striving beyond conflicts would merely conceal genuinely prevailing tensions and fabricate apparitions that served some parties' ideological interests. Striving toward post-politics would thus be a particularly political move, regardless of whether the goal was achieved. The inevitability of the political followed logically from, first, Schmitt's conceptual coupling of the political with the eventuality of war and, second, from his belief in the ineridicability of wars. Schmitt was affectively committed to the category of the political, and war was its guarantee. Jünger, by contrast, was more concerned with the questions of war to begin with and rather treated politics as an extension thereof, and having no comparable conceptual loyalties he could easily afford advocating a transition to the post-political. In fact, such a transition germinated already in 1932, when Jünger, rather than merely developing nationalistic ideas, sketched the framework for future politics from a 'metapolitical' perspective with apocalyptic overtones. This strategy remained in the 1950s. ${ }^{109}$ To cherish human freedom, Jünger now theorized 
resignation, witdrawal from the society, and passive resistance on an individualistic basis, and became a literal-esoteric rather than a properly political thinker.

Second, the end state Jünger envisioned would also be non-historical. Jünger argued for a transition from the historical to the posthistorical period, comparing the present situation with that of Herodotos who, standing on a summit, glanced on both dark prehistory and the dawning historical epoch. The future for Jünger's contemporaries was equally dark and unknown, yet beyond the mythical 'time wall' there would no longer be history as known so far. ${ }^{110}$ The truly planetary perspective was 'metahistorical' as it provided 'glimpses to a world beyond history,' and eventually Earth history would 'infringe human history and terminate it. $^{111}$ While a transition to post-history was allegedly objectively happening in the world, a conscious transition to a new level in the categories of thought was necessary to ensure peace. Already in his wartime diaries Jünger observed that transcending the world of destruction could not succeed 'on the historical plain.'112

The obscure amalgamation of need and factuality made Jünger's prose suggestive rather than analytical, but in stressing a single world-state in a world beyond politics and history, he saliently deviated from Schmitt and Freyer. In his late essays, Schmitt invoked the katechon precisely to protect historicity from the eschatological condition where all demarcations, and thereby the basis of collective identity, would be replaced by cultural unity. Equally, for Freyer, this would spell the end of politics, and by the end of statal decisions with epochal consequences, the end of world history in general. Jünger, by contrast, prioritized the planetary tasks, and in indirectly reckoning with his own military past, he abandoned war for the sake of peace. Rather than deradicalizing his conservatism in the postwar period like 
Freyer, Jünger renounced politics altogether and justified this depoliticization theoretically with an apocalyptic theory of a qualitatively different mode of being after the end of history. ${ }^{113}$ The meta-/postpolitical and the meta-/posthistorical elements were inseparable, and both aspects germinated already in Der Arbeiter, the relevance of which Jünger underscored with a later commentary: not only would the transition of the worker from 'planetary power to planetary order' terminate 'the era of warring states' upon a 'divided Earth' and bring about the world-state, but also time itself was changing and events were no longer historical. ${ }^{114}$ The rupture of 1945 thus merely finalized the postpolitical/posthistorical turn initiated earlier.

\section{Conclusions}

All three radical conservatives posited structural changes of the international system, consisting of an increase in the size of political units and a corresponding decrease in their number. Proceeding from nation-states through federal states to larger spaces and continentwide interest spheres, the development manifested a trend toward world unification. Yet, for these thinkers, unification and universalism implied the end of politics. Their key categories were designed to mediate globality and the political, and thus reflected the inherent paradox in globalizing what emerged in a nationalistic framework to cherish particularity.

First, all three underscored plurality - from Schmitt's note of the political world as a 'pluriverse' to Freyer's thesis of the 'pluralism of the historical world' and Jünger's restatement of a 'pluralism' of other states as a defining feature of a political state. The function of the conceptual tie between plurality and the state was for Schmitt and Freyer to resist global uniformity, whether moral, legal or technological, and they systematically upheld 
this premise also after 1945. Jünger, by contrast, abandoned it for reasons of exigency, underlining that the existence of other states was a characteristic of the state historically, but hoping this could be transcended. ${ }^{115}$ Both solutions were equally consistent; yet both reflect the self-inflicted either/or of political particularity and unpolitical universalism that shackled German radical conservatism.

Second, for all three, the reflection of the Earth as a planet provided the wider categories beyond the sequence national/international/global - qualitatively, rather than merely in terms of extension. The radical conservatives were, certainly, not alone in their planetarity: for instance Ernst Troeltsch followed H. G. Wells in speaking of a 'planetary situation,' and Karl Jaspers, building on Heidegger, equally saw the technical age as an 'absolutely universal' and 'planetary' age. ${ }^{116}$ However, for the radical conservatives, the planetary perspective served several particular functions. It linked Schmitt's theories to considerations of space rather than mere 'internationalism' or abstract liberal normativism. It allowed Freyer to reformulate the possibility of universal history in political terms as the history of the universal effects of European civilization. It enabled Jünger to surpass nationalistic confines first in favor of global apocalyptic visions of work and planning and, eventually, rudimentary ecological perspectives.

Third, technology played a key role in the planetary turn ever since Schmitt's early depiction of 'satanic' technology, Freyer's arguments on technology's universalizing power and Jünger's planetary visions. For all three, technology was not only an index of globalization but also a key factor therein - and as technology manifested Western Enlightenment rationality and was steadily put to political uses, also the consequent global uniformity bore 
distinctively political traits. Technology reflected the Western particularity that emulated universality and produced effects that were political with respect to their origins and inner logic, yet by definition non-political in undermining national differentials. In the radicalconservative framework, the paradoxical nature of technology, I claim, reflected the more fundamental paradox of globalizing the political.

Fourth, this directly implied a position with regard to the question of war - the ultimate manifestation of technical rationality. Modern total wars not only mobilized industrial resources totally but also became global in extension, thus further exemplifying technology's planetary tendency. War, however, was also a political phenomenon par excellence, and technological progress thus globalized the political. Not commerce and cultural exchange, but above all the spreading of political ideologies, conflicts, and warfare as their culmination had made the world situation truly planetary. All three conservatives lamented the substitution ideological crusades for the traditional wars waged with mutual respect, or, in Freyer's formulation, 'the ideologization of world politics and the universalization of the situation of civil war. ${ }^{117}$ This diagnosis suited their need to represent Germany as a collateral victim in an ideological confrontation between (American) liberalism and (Russian) socialism, thereby historically relativizing the German contribution to ideological intensification. More crucially, however, the civil war argument was intimately interlinked with the planetary perspective. In a world-state of planetary proportions, there would empirically still be conflicts, although wars of international scale could presumably be avoided: Jünger in fact considered it utopian to assume the world-state to bring complete peace. ${ }^{118}$ 
Moreover, when reflected from the point of view of the whole Earth, wars were eo ipso internal strifes. This was a major challenge for the radical conservatives' categories, as it appeared to make civil wars inevitable. Jünger was significantly more tolerant than Schmitt, or Freyer following him, toward civil wars. For Schmitt, civil wars were ideological and therefore particularly intense and destructive wars, the absolute evil. Already this premise ruled out a genuinely planetary perspective: although reflected as a whole, the world had to be divided into at least two political spheres in order to maintain regular wars and avoid civil wars. We may critically claim that Schmitt here wrongly amalgamated his point regarding how civil wars were waged with the question of who waged them, that conflicts would not automatically be fiercer simply because they were waged within a global structure and that to use the intensity argument against the world-state therefore was a non sequitur. At any rate, the planetary perspective threathed to turn wars conceptually into civil wars, and Schmitt and Freyer resisted planetarization precisely for this reason, while Jünger maintained planetarity and tolerated minor fraternal strifes. The civil war perspective has since obtained a curious afterlife in analyzes of world terrorism as a form of 'global civil war.,'119

Fifth, the radical conservatives' views on the structural changes of the world system were based on their respective philosophies of history: Schmitt's model of counter-forces upholding history, Freyer's empirical plurality of world history and restraining forces resisting industrial universalism and Jünger's dawning post-history with the eternal recurrence of the same. The three radical conservatives were, obviously, not the first or last to combine state theory with the metaphysics of history. Their predecessors in the end of history debate included Hegel with whom both Freyer and Schmitt engaged, Alexandre Kojève whose second-order Hegelianism fascinated Schmitt, and the fellow-conservative Arnold 
Gehlen whose theory of cultural crystallization and the end of history in the industrial society closely resembled Freyer's. ${ }^{120}$ Fukuyama's post-Cold War thesis on the end of history reinvigorated these considerations. Destined to keep history running, Schmitt and Freyer perceived tendencies of stagnation in the industrial society, yet resisted the end of history theses as well as cyclical views. Despite contrary tendencies of technology-driven uniformity, history understood as plurality would still continue. After jettisoning the Hegelian unity of history and reason, and thereby the idea of a suprahistorical criterion, Freyer sought to make history itself into such a criterion, providing a right-Hegelian form of historicism. Liberated from its unilinearity, universal history was possible as an empirical sum of cultural conquest, differentiation and recognition-seeking: world history was the final frontier beyond which no overarching principle could be found. While this model implied a multi-polar world order, Jünger's philosophy of the overcoming of history suggested a unified world-state. For all three, speculative theology or philosophy of history served to indirectly answer the dilemma of the globalized political - Schmitt's katechon postponing unpolitical universality, Freyer relativizing the quasi-Hegelian political forms into empirical world-history, and Jünger 'nonpoliticizing the political ${ }^{121}$ by renouncing history.

Sixth, the question of what happened to the political in the transition to planetarity runs through all the previous categories, and this problem culminated in the question of the world state - arguably the litmus test for radical conservative categories. Here the three conservatives were again in esteemed company. Declaring nationalism as obsolete, Wells advocated a federal world-state, and after WW2, Arnold Toynbee equally considered world government inevitable in of the atomic age, while Karl Jaspers regarded 'the political unity of the Earth' as merely a matter of time and Hans Morgenthau called for a world-state to secure 
permanent peace. ${ }^{122}$ Schmitt's case was straightforward: the political was a relation between two or more political entities, based on the possibility of war, and the political could therefore only be expanded to greater spaces, not fully globalized. The world-state would be a nonpolitical state, and Schmitt's philosophy of history served to set a limit to unification. Freyer rather historicized the political into a contingent and limitedly available virtù-like substance that enabled countries or continents to rise to political grandeur with universalizing effects. Its consequences were global, but the political itself was a rare and particularistic quality, deriving from national cultural resources. The plurality of the political ultimately precluded the political unity of the world and determined also Freyer's preference for a balance of power.

Jünger took radically diverging routes. 'Conservatives,' Jünger argued, preferred counterpowers and a world divided into three or more parts, while his own preference was a single world-state. ${ }^{123}$ The transition beyond the political and the historical was the theoretical price Jünger was willing to pay for this commitment; or perhaps the grandiose planetary claims reflected a personal choice, induced by guilt, which the institutional commitment to world government then epitomized. Either way, for Jünger, 'a solution to the dilemma of the political' could 'be found only outside of history' and with 'the exclusion of the political in Schmitt's sense,' as noted by Hohendahl. ${ }^{124}$ More precisely, the paradox of the globalized political, I claim, was what drove the reconceptualization.

It was, however, questionably whether the radical-conservative political could be genuinely globalized. On account of the nationalistic-particularist roots of 'the political' and the gradually accumulated auxiliary assumptions, the radical-conservatives had to choose either 
true globality at the price of non-political posthistoire or the genuinely political condition with history, contestation - and planetary civil war. Incapable of solving the riddle in any other manner than by sword, Schmitt, Freyer, and Jünger passed it on to their successors. ${ }^{125}$ Neither alternative is particularly tempting or suitable for addressing the present global challenges. To comprehend and, where suitable, contest contemporary verbalizations of the dilemma, it is crucial to know the particularly ideological stage in the pre-history of European globalization theory this language derives from as well as the key questions the language sought to answer. We comprehend the current calls for globality without universalism better if we understand how they were foreshadowed by the mid- $20^{\text {th }}$-century discourse of 'planetary' anti-universalism. The radical-conservative categories are bound to remain with us, and so is the question of political globalization, regardless of whether it is seen as an empirical trend or a necessity in the face of planetary challenges. A great part of how we respond to these challenges relates to how we frame them. Cognizant of the prehistory of globalization theory and how these historical layers are still mobilized against global political unification, we may better identify the ideological burden involved and ensure that we are solving our conundrums rather than those of our predecessors.

\section{Notes}

${ }^{1}$ Habermas, Postnational Constellation; Held, Democracy and the Global Order; Wendt, 'Why a World State'; Fukuyama, End of History.

${ }^{2}$ Beck, Was ist Globalisierung, 13.

${ }^{3}$ Mouffe, On the Political.

${ }^{4}$ Habermas, Postnational Constellation, 110. 
${ }^{5}$ Of the vast scholarship, space permits mentioning only the best intellectual biographies:

Mehring, Carl Schmitt; Muller, Other God; Schwilk, Ernst Jünger.

${ }^{6}$ Martin Heidegger's analyses of technology and planetarity, largely based on Jünger's ideas, also shaped and disseminated the radical conservative language. Here I exclude Heidegger, as he was scarcely a theorist of the state or the global order. For Heidegger and Jünger, see Morat, Von der Tat.

${ }^{7}$ Odysseos \& Petito, International Political Thought; Legg, Spatiality, Sovereignty, and Carl Schmitt.

${ }^{8}$ Kervégan, “Carl Schmitt”; Petito, “Against World Unity”; Hell, “Katechon.”

${ }^{9}$ Hohendahl, "Reflections on War and Peace."

${ }^{10}$ Jünger's 'planetary’ perspective and Schmitt's lukewarm reception of it have been noted in Breur, Die radikale Rechte, 203-17. Breuer (Anatomie der konservativen Revolution, 104-

114) briefly discusses, amongst others', Freyer's and Jünger's views of empire-building.

${ }^{11}$ Morat, "Entpolitisierung des Politischen."

${ }^{12}$ Bartelson, Visions of World Community, 5, 43, 86-87, 171-5.

${ }^{13}$ Schmitt, Concept of the Political, 53.

${ }^{14}$ Ibid., 54)

${ }^{15}$ Schmitt, "Der Völkerbund und Europa," 94.

${ }^{16}$ Schmitt, "Völkerrechtliche Probleme im Rheingebiet," 108.

${ }^{17}$ Freyer, Staat, 22-23, 98, 107.

${ }^{18}$ Ibid. 99, 111.

${ }^{19}$ Ibid., 145.

${ }^{20}$ Ibid., 146-148.

${ }^{21}$ Ibid., 198. 
${ }^{22}$ Ibid., 197.

${ }^{23}$ Ibid., 197.

${ }^{24}$ Ibid., 209-210.

${ }^{25}$ Ibid., 212.

${ }^{26}$ Ibid., 197.

${ }^{27}$ Peperzak, "Hegel contra Hegel," 257-262.

${ }^{28}$ Freyer, "Ethische Normen," 105-7.

${ }^{29}$ Freyer, Staat, 172.

${ }^{30}$ Ibid., 176, 178.

${ }^{31}$ Ibid., 177-178.

${ }^{32}$ Herf, Reactionary Modernism.

${ }^{33}$ Freyer, Revolution von Rechts.

${ }^{34}$ Jünger, Politische Publizistik, 142, 144, 189.

${ }^{35}$ Ibid., 579

${ }^{36}$ Ibid., 581.

${ }^{37}$ Ibid., 145.

${ }^{38}$ Jünger, Arbeiter, 15-21.

${ }^{39}$ Ibid., 75-77.

${ }^{40}$ Ibid., 147-148, 217.

${ }^{41}$ Ibid., 192, 232.

${ }^{42}$ Ibid., 158-161, 217.

${ }^{43}$ Ibid., 162.

${ }^{44}$ Ibid., 154.

${ }^{45}$ This difference is noted in Breuer, radikale Rechte, 213. 
${ }^{46}$ Wilhelm Stapel, Der christliche Staatsman, cited in Breuer, Anatomie der konservativen Revolution, 107.

${ }^{47}$ Schmitt, "Raum und Großraum,” 235-237.

${ }^{48}$ Schmitt, Völkerrechtliche Großraumordnung, 306.

${ }^{49}$ Schmitt, "Raum und Großraum," 235, 250-251.

${ }^{50}$ Schmitt, Völkerrechtliche Großraumordnung, 305-306.

${ }^{51}$ Schmitt, "Raum und Großraum," 250; Schmitt, "Auflösung der europäischen Ordnung," 381-382.

${ }^{52}$ Schmitt, "Beschleuniger wider Willen,” 433; Schmitt, "Raumrevolution,” 389.

${ }^{53}$ Schmitt, "Neutralität und Neutralisierungen," 286.

${ }^{54}$ Schmitt, Nomos of the Earth, 243, 351.

${ }^{55}$ Ibid., 226-230, 238, 296.

${ }^{56}$ Freyer, Herrschaft und Planung.

${ }^{57}$ Schmitt, "Drei Stufen historischer Sinngebung," 927.

${ }^{58}$ Ibid., 930.

${ }^{59}$ Cf. Pankakoski, "Carl Schmitt Versus the 'Intermediate State," 264.

${ }^{60}$ Schmitt, "Einheit der Welt," 496.

${ }^{61}$ Ibid., 499-500.

${ }^{62}$ Ibid., 504.

${ }^{63}$ Schmitt, "geschichtliche Struktur," 531-532.

${ }^{64}$ Ibid., 525.

${ }^{65}$ Schmitt, Glossarium, 17.

${ }^{66}$ Schmitt, "Ordnung der Welt," 601.

${ }^{67}$ Ibid., 602-603. 
${ }^{68}$ Freyer, "Weltgeschichte," 143-145.

${ }^{69}$ Ibid., 146.

${ }^{70}$ Freyer, Weltgeschichte Europas, 33-34, 51-53.

${ }^{71}$ Freyer, "Politische als Problem," 53.

${ }^{72}$ Ibid., 61.

${ }^{73}$ Ibid., 63; Freyer, Machiavelli, 79, 99-101, 149, 165.

${ }^{74}$ Freyer, Weltgeschichte Europas, 693-694, 727.

${ }^{75}$ Ibid., 55-66, 91.

${ }^{76}$ Ibid., 962-963.

${ }^{77}$ Ibid., 793.

${ }^{78}$ Ibid., 966.

${ }^{79}$ Ibid., 970-971.

${ }^{80}$ Ibid., XI.

${ }^{81}$ Ibid., 947, 995.

${ }^{82}$ Freyer, Theorie des gegenwärtigen Zeitalters, 79.

${ }^{83}$ Ibid., 60.

${ }^{84}$ Ibid., 70.

${ }^{85}$ Ibid., 249-250.

${ }^{86}$ Freyer, Weltgeschichte Europas, 852-859.

${ }^{87}$ Freyer, Theorie des gegenwärtigen Zeitalters, 72.

${ }^{88}$ Ibid., 252.

${ }^{89}$ Ibid., $72-73$.

${ }^{90}$ Ibid., 260.

${ }^{91}$ Jünger, Strahlungen II, 113. 
92 Jünger, “Friede,” 198, 211.

${ }^{93}$ Ibid., 195, 211.

${ }^{94}$ Ibid., 233-234.

${ }^{95}$ Ibid., 211.

${ }^{96}$ Ibid., 209, 228.

${ }^{97}$ Ibid., 222-225.

${ }^{98}$ Ibid., 262.

${ }^{99}$ Jünger, Weltstaat, 21.

${ }^{100}$ Ibid., 21, 23.

${ }^{101}$ Ibid., 23.

${ }^{102}$ Ibid., 30.

${ }^{103}$ Ibid., 73.

${ }^{104}$ Ibid., 33.

${ }^{105}$ Ibid., 75.

${ }^{106}$ Jünger, An der Zeitmauer, 176.

${ }^{107}$ Ibid., 175.

${ }^{108}$ Ibid., 194, 197.

${ }^{109}$ Morat, Von der Tat, 426-428.

110 Jünger, An der Zeitmauer, 97, 100.

${ }^{111}$ Ibid., 138, 307.

112 Jünger, Strahlungen II, 149.

${ }^{113}$ Morat, Von der Tat, 15-16; Muller, Other God.

114 Jünger, Maxima-Minima, 344-345.

115 Jünger, Weltstaat, 76; Jünger, Maxima-Minima, 345. 
${ }^{116}$ Troeltsch, Historismus und seine Probleme, 712; Jaspers, Ursprung und Ziel, 178.

${ }^{117}$ Freyer, Schwelle der Zeiten, 291. Cf. Jünger, “Friede,” 198, 211.

118 Jünger, Maxima-Minima, 391.

${ }^{119}$ Mouffe, “Cosmopolitics or Multipolarity,” 22; Agamben, Stasis, 18.

${ }^{120}$ Niethammer, Posthistoire.

${ }^{121}$ Cf. Morat, "Entpolitisierung des Politischen."

${ }^{122}$ Wells, Outline of History, 1087; Toynbee, "International Outlook"; Jaspers, Ursprung und

Ziel, 242; Morgenthau, Politics among Nations, 509.

${ }^{123}$ Jünger, Maxima-Minima, 397.

${ }^{124}$ Hohendahl, "Reflections on War and Peace," 42-43.

${ }^{125}$ For instance Hardt and Negri (Empire, 19, 26) clearly spoke the language of mid- $20^{\text {th }}-$ century radical conservatism when they analyzed the transition from the logic of imperialism to that of Empire and identified 'the material constitution of the new planetary order,' 'the production of new hierarchies of command over global space,' as well as attempts to treat 'the universal, planetary sphere as a single, systemic set.' Chantal Mouffe (“Cosmopolitics or Multipolarity," 26) moved in the same discursive tradition in calling for a 'multipolar' and 'pluralistic world order' rather than the vain hope that a unipolar world order would overcome antagonisms by 'a unification of the world' in which 'the political, conflict and negativity' would be transcended. Mouffe (On the Political, 87, 91, 115) also underlined 'the deeply pluralistic nature of the world' and explicitly turned Schmitt's dictum of the world as a 'pluriverse' against the US hegemony and other attempts 'towards the unification of the planet.' Also the Russian version of multipolarity, based on sovereign states' balance of power, as an alternative to globalization has been legitimized with arguments close, and by no 
means coincidentally, reminiscent of Schmitt (see Makarychev and Morozov, “Multilateralism, Multipolarity, and Beyond,” 361).

\section{Bibliography}

Agamben, Giorgio. Stasis: Civil War as a Political Paradigm. Translated by Nicholas Heron. Edinburgh: Edinburgh University Press, 2015.

Bartelson, Jens. Visions of World Community. Cambridge: Cambridge University press, 2009.

Beck, Ulrich. Was ist Globalisierung? Zweite Auflage. Frankfurt am Main: Suhrkamp, 1997.

Breuer, Stefan. Anatomie der konservativen Revolution. Darmstadt: Wissenschaftliche Buchgesellschaft, 1993.

Breuer, Stefan. Die radikale Rechte in Deutschland 1871-1945. Stuttgart: Reclam, 2010.

Freyer, Hans. “Ethische Normen und Politik.” Kant-Studien 35 (1930): 99-114.

Freyer, Hans. Herrschaft, Planung und Technik: Aufsätze zur politischen Soziologie, ed.

Elfriede Üner. Weinheim: VCH, 1987. [=HPT]

Freyer, Hans. Herrschaft und Planung: Zwei Grundbegriffe der politischen Ethik [1933], in HPT, 17-43. 
Freyer, Hans. Machiavelli. Leipzig: Bibliographisches Institut, 1938.

Freyer, Hans. "Das Politische als Problem der Philosophie” [1935]. In HPT, 45-64.

Freyer, Hans. Revolution von Rechts. Jena: Diederichs, 1931.

Freyer, Hans. Schwelle der Zeiten: Beiträge zur Soziologie der Kultur. Stuttgart: Deutsche Verlags-Anstalt, 1965.

Freyer, Hans. Der Staat. Leipzig: Rechfelden, 1925.

Freyer, Hans. Theorie des gegenwärtigen Zeitalters. Stuttgart: Deutsche Verlags-Anstalt, 1955.

Freyer, Hans. "Weltgeschichte.” Die Sammlung 2 (1947): 143-152.

Freyer, Hans. Weltgeschichte Europas, 2 vols. Wiesbaden: Dieterich, 1948.

Fukuyama, Francis. The End of History and the Last Man. New York: Free Press, 1992.

Hardt, Michael, and Antonio Negri. Empire. Cambridge, MA: Harvard University Press, 2000. 
Habermas, Jürgen. The Postnational Constellation: Political Essays. Translated by Max Pensky. Cambridge, UK: Polity, 2007[1998].

Held, David. Democracy and the Global Order: From the Modern State to Cosmopolitan Governance. Cambridge, UK: Polity, 1995.

Hell, Julia. "Katechon: Carl Schmitt's Imperial Theology and the Ruins of the Future.” The Germanic Review 84, no. 4 (2009): 283-326.

Herf, Jeffrey. Reactionary Modernism: Technology, Culture, and Politics in Weimar and the Third Reich. Cambridge, UK: Cambridge University Press, 1984.

Hohendahl, Peter Uwe. "Reflections on War and Peace after 1940: Ernst Jünger and Carl Schmitt." Cultural Critique 69 (2008): 22-51.

Jaspers, Karl. Vom Ursprung und Ziel der Geschichte. München: Piper, 1949.

Jünger, Ernst. An der Zeitmauer. Stuttgart: Klett, 1959.

Jünger, Ernst. Der Arbeiter: Herrschaft und Gestalt. Hamburg: Hanseatische Verlagsanstalt, 1932.

Jünger, Ernst. Der Friede [1945]. In: Sämtliche Werke 7. Stuttgart: Klett-Cotta, 2002, 193236. 
Jünger, Ernst. Maxima-Minima: Adnoten zum 'Arbeiter.' In: Werke 6. Stuttgart: Klett, 1964, $331-403$.

Jünger, Ernst. Politische Publizistik: 1919 bis 1933. Edited by Sven Olaf Berggötz. Stuttgart: Klett-Cotta, 2001.

Jünger, Ernst. Strahlungen II: Sämtliche Werke, 3. Stuttgart: Klett-Cotta, 1998.

Jünger, Ernst. Der Weltstaat: Organismus und Organisation. Stuttgart: Klett, 1960.

Kervégan, Jean-François. "Carl Schmitt and 'World Unity." In The Challenge of Carl Schmitt, edited by Chantal Mouffe, 54-74. London: Verso, 2000.

Legg, Stephen (ed.). Spatiality, Sovereignty and Carl Schmitt: Geographies of the Nomos. London: Routledge, 2011.

Makarychev, Andrey, and Viatcheslav Morozov. "Multilateralism, Multipolarity, and Beyond: A Menu of Russia’s Policy Strategies.” Global Governance 17, no. 3 (2011): 353373.

Mehring, Reinhard. Carl Schmitt: Aufstieg und Fall. Munich: Beck, 2009. 
Morat, Daniel. “Die Entpolitisierung des Politischen: Ernst Jünger’s Essayistik der 1950er Jahre.” In Ernst Jünger und die Bundesrepublik: Ästhetik - Politik - Zeitgeschichte, edited by Matthias Schöning \& Ingo Stöckmann, 163-183. Berlin: de Gruyter, 2012.

Morat, Daniel. Von der Tat zur Gelassenheit: Konservatives Denken bei Martin Heidegger, Ernst Jünger und Friedrich Georg Jünger 1920-1960. Göttingen: Wallstein, 2008.

Kervégan, Jean-François. "Carl Schmitt and 'World Unity."” In The Challenge of Carl Schmitt, edited by Chantal Mouffe, 54-74. London: Verso, 2000.

Morgenthau, Hans. Politics among Nations: The Struggle for Power and Peace. New York: Knopf, 1961[1949].

Mouffe, Chantal. “Cosmopolitics or Multipolarity?” Redescriptions 9 (2005): 15-26.

Mouffe, Chantal. On the Political. London: Routledge, 2005.

Muller, Jerry Z. The Other God that Failed: Hans Freyer and the Deradicalization of German Conservatism. Princeton: Princeton University Press, 1987.

Niethammer, Lutz. Posthistoire: Has History Come to an End? Translated by Patrick Camiller. London: Verso, 1994. 
Odysseos, Louisa, and Fabio Petito (eds.). The International Political Thought of Carl Schmitt: Terror, Liberal War and the Crisis of Global Order. London: Routledge, 2007.

Pankakoski, Timo. “Carl Schmitt Versus the 'Intermediate State': International and Domestic Variants." History of European Ideas 39, no. 2 (2013), 241-66.

Peperzak, Adriaan Theodoor. "Hegel contra Hegel in His Philosophy of Right: the Contradictions of International Politics.” Journal of the History of Philosophy 32, no. 2 (1994): 241-63.

Petito, Fabio. "Against World Unity: Carl Schmitt and the Western-Centric and Liberal Global Order." In: The International Political Thought of Carl Schmitt: Terror, Liberal War and the Crisis of Global Order, edited by Louisa Odysseos and Fabio Petito, 166-184. London: Routledge, 2007.

Schmitt, Carl. "Auflösung der europäischen Ordnung im 'International Law”" [1940]. In: SGN, 372-387.

Schmitt, Carl. "Beschleuniger wider Willen, oder: Problematik der westlichen Hemisphäre," [1942]. In: SGN, 431-340.

Schmitt, Carl. The Concept of the Political. Translated by George Schwab. Chicago: University of Chicago Press, 2007[1932].

Schmitt, Carl. "Drei Stufen historischer Sinngebung.” Universitas 5 (1950): 927-931. 
Schmitt, Carl. “Die Einheit der Welt,” [1952]. In: SGN, 496-512.

Schmitt, Carl. "Die geschichtliche Struktur des heutigen Welt-Gegensatzes von Ost und West: Bemerkungen zu Ernst Jüngers Schrift: 'Der Gordische Knoten.’” [1955]. In: SGN, 523-551.

Schmitt, Carl. Glossarium: Aufzeichnungen der Jahre 1947-1951. Edited by Eberhard Freiherr von Medem. Berlin: Duncker \& Humblot, 1991.

Schmitt, Carl. "Neutralität und Neutralisierungen” [1939]. In: PB, 271-295.

Schmitt, Carl. The Nomos of the Earth in the International Law of the Jus Publicum Europaeum Translated by G. L. Ulmen. New York: Telos, 2003[1950].

Schmitt, Carl. "Die Ordnung der Welt nach dem Zweiten Weltkrieg," [1962]. In: SGN, 592618.

Schmitt, Carl. Positionen und Begriffe im Kampf mit Weimar-Genf-Versailles 1923-1939. Berlin: Duncker \& Humblot, 1988. [=PB]

Schmitt, Carl. "Raum und Großraum im Völkerrecht” [1940]. In: SGN, 234-268.

Schmitt, Carl. "Die Raumrevolution: Durch den totalen Krieg zu einem totalen Frieden," [1940]. In: SGN, 388-394. 
Schmitt, Carl. Staat, Großraum, Nomos: Arbeiten aus den Jahren 1916 bis 1969. Edited by Günter Maschke. Berlin: Duncker \& Humblot, 1995. [=SGN]

Schmitt, Carl. "Der Völkerbund und Europa” [1928]. In: PB, 88-97.

Schmitt, Carl. Völkerrechtliche Großraumordnung mit Interventionsverbot für raumfremde Mächte: Ein Beitrag zum Reichsbegriff im Völkerrecht [1939/1941]. In: SGN, 269-371.

Schmitt, Carl. "Völkerrechtliche Probleme im Rheingebiet" [1928]. In: PB, 97-108.

Schwilk, Heimo. Ernst Jünger: Ein Jahrhundertleben. München: Piper, 2007.

Toynbee, Arnold. “The International Outlook.” International Affairs 23, no. 4 (1947): 463476.

Troeltsch, Ernst. Der Historismus und seine Probleme: Erstes Buch: Das logische Problem der Geschichtsphilosophie. Tübingen: Mohr, 1922.

Wells, H. G. The Outline of History. New York: Garden City, 1930[1920].

Wendt, Alexander. "Why a World State is Inevitable.” European Journal of International Relations 9, no. 4 (2003): 491-542. 